\title{
Testing the Disinhibition Hypothesis of Epileptogenesis In Vivo and during Spontaneous Seizures
}

\author{
Paul S. Buckmaster, ${ }^{1}$ Ana L. Jongen-Rêlo, ${ }^{2}$ Shahriar B. Davari, ${ }^{3}$ and Emilia H. Wong1 \\ 1 Departments of Comparative Medicine and Neurology and Neurological Sciences, Stanford University School of Medicine, \\ Stanford, California 94305-5410, ${ }^{2}$ Behavioral Neurobiology Laboratory, Swiss Federal Institute of Technology, Zurich, \\ Schwerzenbach, CH-8603, Switzerland, and ${ }^{3}$ School of Medicine, University of California-Davis, Davis, California 95616
}

\begin{abstract}
The "disinhibition" hypothesis contends that (1) seizures begin when granule cells in the dentate gyrus of the dorsal hippocampus are disinhibited and (2) disinhibition occurs because GABAergic interneurons are excessively inhibited by other GABAergic interneurons. We tested the disinhibition hypothesis using the experimental model that inspired it-naturally epileptic Mongolian gerbils. To determine whether there is an excess of GABAergic interneurons in the dentate gyrus of epileptic gerbils, as had been reported previously, GABA immunocytochemistry, in situ hybridization of GAD67 mRNA, and the optical fractionator method were used. There were no significant differences in the numbers of GABAergic interneurons. To determine whether granule cells in epileptic gerbils were disinhibited during the interictal period, IPSPs were recorded in vivo with hippocampal circuits intact in urethane-anesthetized gerbils. The reversal potentials
\end{abstract}

and conductances of IPSPs in granule cells in epileptic versus control gerbils were similar. To determine whether the level of inhibitory control in the dentate gyrus transiently decreases before seizure onset, field potential responses to paired-pulse perforant path stimulation were obtained from the dorsal hippocampus while epileptic gerbils experienced spontaneous seizures. Evidence of reduced inhibition was found after, but not before, seizure onset, indicating that seizures are not triggered by disinhibition in this region. However, seizure-induced depression of inhibition may amplify and promote the spread of seizure activity to other brain regions. These findings do not support the disinhibition hypothesis and suggest that in this model of epilepsy seizures initiate by another mechanism or at a different site.

Key words: epilepsy; seizure; dentate gyrus; hippocampus; GABA; GAD; inhibition; gerbil; in vivo
The causes of epileptic seizure initiation are poorly understood. Failure of inhibitory control may underlie spontaneous seizures. Possible mechanisms include insufficient GABA release (During et al., 1995), the loss of GABAergic interneurons (de Lanerolle et al., 1989; Obenaus et al., 1993), changes in circuits involving GABAergic interneurons (Sloviter, 1987; Bekenstein and Lothman, 1993), and changes in the expression of $\mathrm{GABA}_{\mathrm{A}}$ receptors (Buhl et al., 1996; Brooks-Kayal et al., 1998). The "disinhibition" hypothesis proposes another possible mechanism of inhibitory failure and seizure genesis (Peterson and Ribak, 1989). According to this hypothesis, seizures start because granule cells in the dentate gyrus of the dorsal hippocampus are disinhibited. Granule cells are disinhibited because there are too many GABAergic interneurons and too many inhibitory synaptic contacts between GABAergic interneurons, so that GABAergic interneurons inhibit one another, leaving granule cells inadequately inhibited.

The disinhibition hypothesis arose from work with Mongolian gerbils (Peterson and Ribak, 1989), which display a high incidence of inherited epilepsy (Loskota et al., 1974). Evidence consistent with the disinhibition hypothesis includes the following: Electrographic seizures have been recorded in the hippocampus of epileptic gerbils (Loskota and Lomax, 1975; Majkowski and Donadio, 1984). There is ultrastructural evidence of accelerated synaptic vesicle recycling in the mossy fibers of granule cells in epileptic gerbils (Paul et al., 1981). Lesioning the perforant path-the main excitatory synaptic input to the dentate gyrus-blocks seizures in epileptic gerbils (Ribak and Khan, 1987). Epileptic gerbils are reported to have excess GABAergic interneurons in the dentate gyrus, but not in other brain regions (Peterson et al., 1985; Peterson

\footnotetext{
Received Feb. 24, 2000; revised April 25, 2000; accepted May 23, 2000.

This work was supported by the Epilepsy Foundation of America. Paul Buckmaster is a recipient of a Career Award from the Burroughs Wellcome Fund. We are grateful to Dr. David Amaral for his support and encouragement.

Correspondence should be addressed to Dr. Paul S. Buckmaster, Department of Comparative Medicine, Building 330, Quad 7, RAF-1, Stanford University School of Medicine, Stanford, CA 94305-5410. E-mail: psb@stanford.edu.

Copyright (C) 2000 Society for Neuroscience $0270-6474 / 00 / 206232-09 \$ 15.00 / 0$
}

and Ribak, 1987). And epileptic gerbils are reported to have excess inhibitory synapses contacting GABAergic interneurons in the dentate gyrus of the dorsal hippocampus (Peterson et al., 1985; Farias et al., 1992).

A disinhibitory mechanism might contribute to seizure genesis in temporal lobe epilepsy - the most common type of epilepsy in adults (Engel et al., 1997). In the dentate gyrus of patients and models of temporal lobe epilepsy, many excitatory neurons are missing, but GABAergic interneurons are relatively spared, and they appear to sprout axon collaterals and form new inhibitory synapses (Babb et al., 1989; Davenport et al., 1990; Mathern et al., 1995). Granule cells from temporal lobe epilepsy patients are reported to be less inhibited than those in controls, even when excitatory synaptic transmission is blocked (Williamson et al., 1999). These findings suggest that granule cells may be disinhibited because GABAergic interneurons are hyperinnervated by other GABAergic interneurons.

We tested the disinhibition hypothesis in naturally epileptic gerbils by counting the number of GABAergic interneurons in the dentate gyrus using two cell markers and modern stereological techniques, by measuring IPSPs in granule cells with neuronal circuits intact in urethane-anesthetized gerbils in vivo, and by measuring the level of inhibition in the dentate gyrus as epileptic gerbils experienced spontaneous seizures. Our findings do not support the disinhibition hypothesis and suggest that in this experimental model seizures arise by another mechanism or in a different region of the brain.

\section{MATERIALS AND METHODS}

\section{Animals}

The gerbils (Meriones unguiculatus) used in these experiments came from our colony in which animals are selectively bred for or against the epilepsy trait. Gerbils were screened for seizure sensitivity by exposing them to a novel environment, as described previously (Buckmaster et al., 1996). Briefly, gerbils were transferred individually from their home cage to a red plastic basket, which is similar to a previously described optimal stimulus for inducing seizures in epileptic gerbils (Ludvig et al., 1991), and they 
were observed for signs of motor seizures (facial clonus, head nodding, forelimb clonus, and generalized convulsions).

\section{Anatomy}

Approximately equal numbers of male and female gerbils, 5-9 months old, were used. All of the seizure-sensitive gerbils $(n=5)$ displayed seizures in at least three of four novel environment exposures. None of the seizureresistant gerbils $(n=6)$ were observed to have a seizure during four novel environment exposures or at any other time. Gerbils were killed by pentobarbital overdose (100 $\mathrm{mg} / \mathrm{kg}$, i.p.) and perfused at $15 \mathrm{ml} / \mathrm{min}$ through the ascending aorta for 2 min with $0.9 \% \mathrm{NaCl}$ followed by $30 \mathrm{~min}$ with $4 \%$ paraformaldehyde and $0.5 \%$ glutaraldehyde in $0.1 \mathrm{M}$ phosphate buffer (PB), pH 7.4, at $4^{\circ} \mathrm{C}$. Brains were removed and post-fixed in the same fixative overnight at $4^{\circ} \mathrm{C}$. The hippocampus was isolated and cryoprotected in $30 \%$ sucrose in PB before being sectioned in its entirety, perpendicular to the septotemporal axis, with a sliding microtome set at $30 \mu \mathrm{m}$. Sections were kept in serial order and stored at less than $-20^{\circ} \mathrm{C}$ in $30 \%$ ethylene glycol and $25 \%$ glycerol in $50 \mathrm{~mm}$ PB that was treated with diethylpyrocarbonate to inactivate RNase activity.

GABA immunocytochemistry. A $1 / 20$ series of sections was washed with $0.02 \mathrm{M}$ potassium PBS (KPBS), $\mathrm{pH} 7.4$, and then exposed to $1 \% \mathrm{H}_{2} \mathrm{O}_{2}$ in KPBS for $30 \mathrm{~min}$. Sections were placed in blocking solution consisting of $2 \%$ bovine serum albumin (BSA), $10 \%$ horse serum (HS), and $0.3 \%$ Triton $\mathrm{X}-100$ in KPBS for $4 \mathrm{hr}$, before exposure to a previously characterized (Szabat et al., 1992) monoclonal mouse anti-GABA serum $(1: 3000$ 115AD5; generous gift from Dr. Ismo Virtänen) diluted in 2\% BSA, $1 \%$ $\mathrm{HS}$, and $0.3 \%$ Triton X-100 in KPBS for $60 \mathrm{hr}$ at $4^{\circ} \mathrm{C}$. Sections were rinsed in $2 \% \mathrm{HS}$ in KPBS and then exposed to biotinylated horse anti-mouse serum $(1: 200)$ in $2 \%$ BSA, $1 \%$ HS, and $0.3 \%$ Triton X-100 in KPBS for 1 hr. Sections were rinsed in $2 \%$ HS in KPBS and then exposed to avidinbiotin-horseradish peroxidase (Biomeda, Foster City, CA) in $2 \%$ BSA and $0.3 \%$ Triton X-100 in KPBS for 45 min. After rinsing in $2 \% \mathrm{HS}$ in KPBS, sections were recycled via the secondary antibody solution for $45 \mathrm{~min}$, rinsed in KPBS, and then recycled via the ABC solution for $30 \mathrm{~min}$. Sections were rinsed in KPBS and then placed in the chromogen solution, consisting of $0.03 \%$ diaminobenzidine, $0.3 \% \beta$-D-glucose, $0.05 \% \mathrm{NH}_{4} \mathrm{Cl}$ and $0.002 \%$ glucose oxidase in KPBS, for $20-25 \mathrm{~min}$. The reaction was stopped in rinses of KPBS. Sections were mounted and dried on gelatincoated slides, and staining was intensified with $\mathrm{OsO}_{4}$ and thiocarbohydrazide, as described previously (Buckmaster and Jongen-Rêlo, 1999), before sections were cleared and coverslipped with DPX.

$G A D$ in situ hybridization. Previous studies of epileptic gerbils have used immunocytochemical techniques to detect glutamic acid decarboxylase (GAD)-containing cells as a measure of GABAergic neuron numbers (Peterson et al., 1985; Peterson and Ribak, 1989). More recently, Houser and colleagues have demonstrated in rats that GABAergic neurons in the dentate gyrus are labeled more reliably with in situ hybridization of GAD mRNA than with immunocytochemical methods (Obenaus et al., 1993; Houser and Esclapez, 1994; Esclapez and Houser, 1995). Two subtypes of GAD - GAD65 and GAD67-have been found to be sensitive markers of GABAergic neurons (Houser and Esclapez, 1994; Fukuda et al., 1997; Jongen-Rêlo et al., 1999). Pilot experiments on gerbil tissue revealed stronger labeling for GAD67 mRNA than GAD65 mRNA, and we therefore chose GAD67 mRNA for the marker of GABAergic neurons in these experiments. In situ hybridization was performed on a $1 / 20$ series of sections as described previously (Houser and Esclapez, 1994; Buckmaster and Jongen-Rêlo, 1999). Briefly, rat GAD67 RNA probes were obtained by in vitro transcription of previously described GAD cDNA (kindly provided by Dr. A. Tobin, University of California-Los Angeles). RNA probes were produced by transcription of GAD67 DNA using a nonradioactive RNAlabeling kit (Boehringer Mannheim, Indianapolis, IN). Sections were washed in $10 \mathrm{~mm}$ PBS and sequentially incubated in $0.01 \%$ Triton X-100 (Sigma, St. Louis, MO) in PBS, $0.2 \mu \mathrm{g} / \mathrm{ml}$ Proteinase K (Sigma) and $5 \mathrm{~mm}$ EDTA (Sigma) in $50 \mathrm{~mm}$ Tris, pH 7.4 (Sigma), and $2 \mathrm{mg} / \mathrm{ml}$ glycine (Sigma) in PBS. Sections were prehybridized for $1 \mathrm{hr}$ in a solution containing 50\% formamide (Fluka, Ronkonkoma, NY), $750 \mathrm{~mm} \mathrm{NaCl}$ (Sigma), $25 \mathrm{~mm}$ EDTA, $25 \mathrm{~mm}$ piperazine- $N, N^{\prime}$-bis-2-ethanesulfonic acid (Sigma), 0.2\% SDS, $0.02 \%$ Ficoll (BDH Chemicals, Carle Place, NY) $0.02 \%$ polyvinylpyrrolidone (BDH Chemicals), $0.02 \%$ bovine serum albumin (BDH Chemicals), $250 \mu \mathrm{g} / \mathrm{ml}$ polyA (Sigma), and $250 \mu \mathrm{g} / \mathrm{ml} \mathrm{salmon}$ sperm DNA (Boehringer Mannheim). Sections were hybridized for 16-19 hr in a humid chamber at $50^{\circ} \mathrm{C}$ in a solution consisting of the prehybridization solution with the addition of the digoxigenin-labeled RNA probe at a concentration of $2-4 \mu \mathrm{l} / \mathrm{ml}$, with $100 \mathrm{~mm}$ dithiothreitol (Boehringer Mannheim), 4\% dextran sulfate (Sigma), and $250 \mu \mathrm{g} / \mathrm{ml}$ tRNA (Boehringer Mannheim). After hybridization, sections were subjected to RNase treatment and stringency washes, as described previously (Jongen-Rêlo et al., 1999). Sections were processed for immunodetection of the digoxigenin label with reagents of the nonradioactive nucleic acid detection kit (Boehringer Mannheim). Sections were then mounted on gelatin-coated slides and coverslipped with Crystalmount and Permount (Biomeda).

Analysis. Cell counting was performed by an investigator who was blind to the gerbils' seizure classification. The border between the hilus and the CA3 pyramidal cell layer in the temporal hippocampus of gerbils can be defined in different ways. As it approaches the dentate gyrus, the dense CA3 pyramidal cell layer abruptly becomes diff use and folds back on itself. For these experiments, the border between the hilus of the dentate gyrus and the CA3 field was drawn as straight lines from the tips of the granule cell layer to the proximal tip of the cell-dense part of the CA3 pyramidal cell layer.

For GABA-immunolabeled sections, the optical fractionator method could not be used because structures in the middle of the section thickness were labeled unreliably. The density of GABA-immunoreactive neuronal profiles was measured using a microscope (Axioskop; Zeiss) equipped with a motorized stage (Ludl Electronic Products, Hawthorne, NY), Lucivid (MicroBrightField, Colchester, VT), and Stereo Investigator software (MicroBrightField) to outline the dentate gyrus and count the GABA-positive soma profiles. Values were plotted with respect to the sections' position along the septotemporal axis of the hippocampus. Values from the complete series of sections were averaged to yield a mean density of GABAimmunoreactive neurons per dentate gyrus.

The optical fractionator method (West et al., 1991) was used to estimate the number of GAD67 mRNA-positive neurons per dentate gyrus, as described previously (Buckmaster and Jongen-Rêlo, 1999). Starting from a random position near the septal pole of the hippocampus, a $1 / 20$ series of sections was analyzed. The average number of sections analyzed per hippocampus was 10. Total section thickness was used for dissector height, and only labeled somata that were not cut at the upper surface of the section were counted. This modification of the optical fractionator method facilitates the analysis of tissue sectioned thinly to enhance staining; however, it increases the probability of underestimating cell numbers. There would be no effect on the relative values of seizure-resistant versus seizure-sensitive gerbils, because both groups were analyzed identically. To estimate the number of GAD67 mRNA-positive neurons per dentate gyrus, we sampled $16 \%$ of the area of the dentate gyrus randomly and systematically (counting frame, $40 \times 40 \mu \mathrm{m}$; counting grid, $100 \times 100 \mu \mathrm{m}$ ). Ân average of 148 cells was counted per dentate gyrus.

\section{In vivo intracellular recording}

Twelve seizure-resistant and 11 seizure-sensitive gerbils of both sexes were used to obtain current-clamp recordings of IPSPs in granule cells. The axon projections of inhibitory neurons in the dentate gyrus extend beyond the limits of a standard hippocampal slice (Struble et al., 1978; Han et al., 1993; Buckmaster and Schwartzkroin, 1995; Sik et al., 1997), raising the possibility that the pathogenic disinhibitory circuits may be disrupted by hippocampal slice preparation. Therefore, we used an in vivo intracellular approach to measure IPSPs in granule cells. Gerbils were anesthetized with urethane $(1.5 \mathrm{gm} / \mathrm{kg}$, i.p.) and placed in a stereotaxic frame with the nose bar set at $-3.0 \mathrm{~mm}$. Urethane was used because it produces longlasting and stable anesthesia (Buelke-Sam et al., 1978) and has little effect on GABAergic inhibition in the dentate gyrus (Shirasaka and Wasterlain, 1995). Body temperature was maintained by a heating pad with feedback control. CSF was drained from the cisterna magna to improve stability. Holes were drilled through the skull, and electrodes were directed toward the dentate gyrus and angular bundle at the following coordinates (relative to bregma): $-3.3 \mathrm{~mm}$ posterior and $2.45 \mathrm{~mm}$ lateral for the recording electrode and $-5.0 \mathrm{~mm}$ posterior and $4.3 \mathrm{~mm}$ lateral for the stimulating electrode. Electrode depths were determined by optimizing field potential responses to stimulation. A bipolar concentric stimulating electrode (SNEX-100; Rhodes Medical Instruments, Tujunga, CA) activated perforant pathway fibers. A glass micropipette filled with $0.9 \% \mathrm{NaCl}$ and broken to an inner diameter of $\sim 15 \mu \mathrm{m}$ was used to obtain field potential recordings to measure the depth of the granule cell layer and determine the stimulus threshold for a population spike $(\mathrm{T})$. Then a sharp intracellular electrode, measuring $80-150 \mathrm{M} \Omega$ in vivo and filled with $1 \mathrm{M}$ potassium acetate and $2 \%$ biocytin, was lowered toward the dentate gyrus of the dorsal hippocampus where granule cells were impaled.

Membrane and field potentials were amplified (Axoclamp-2B; Axon Instruments, Foster City, CA), observed on-line, and stored on videotape (Neuro-corder; Neuro Data Instruments, Delaware Water Gap, PA) and on computer (pCLAMP; Axon Instruments) for off-line analysis. The resting membrane potential was determined by subtracting the extracellular voltage measured when the electrode was withdrawn from the cell from the resting intracellular voltage. Input resistance was measured from responses to $0.1-0.5 \mathrm{nA}$ hyperpolarizing current pulses. From responses to depolarizing current injection just large enough to evoke one action potential, action potential amplitude was measured from the onset to the peak value. IPSPs were evoked by activation of perforant path fibers at 0.1 $\mathrm{Hz}$ by $150 \mu \mathrm{sec}$ constant-current pulses. The standardized stimulus intensity for IPSP analysis was $1.5 \times$ T. Fast IPSPs were measured at a $20 \mathrm{msec}$ latency after the stimulus; slow IPSPs were measured at a $150 \mathrm{msec}$ latency. DC current was used to alter the membrane potential and change the amplitude and polarity of postsynaptic potentials. IPSP amplitude was plotted against the prestimulus membrane potential, and the data were fit with a least-squares regression line to determine the IPSP reversal potential. IPSP conductance was calculated by subtracting the cell's input conductance before stimulation from its conductance during the IPSP. Conductance is the slope of $I-V$ curves, where $I$ is the DC holding current and $V$ is the membrane potential.

After intracellular recordings were obtained, cells were labeled with $2 \%$ biocytin so that their granule cell identity could be verified by morphological criteria (Ramón y Cajal, 1995). Cells were iontophoretically injected with $300 \mathrm{msec}$ pulses up to $0.5 \mathrm{nA}$ of hyperpolarizing current for up to 15 $\mathrm{min}$. The gerbil was killed with pentobarbital $(100 \mathrm{mg} / \mathrm{kg}$, i.p.) and then 
perfused through the ascending aorta with $4 \%$ paraformaldehyde in $\mathrm{PB}$, as described above. The hippocampus containing the labeled cell was isolated, cryoprotected in 30\% sucrose in PB, and sectioned perpendicular to the septotemporal axis with a sliding microtome set at $60 \mu \mathrm{m}$. Serial sections were mounted on a gelatin-coated slide and exposed to $0.5 \% \mathrm{H}_{2} \mathrm{O}_{2}$ and $10 \%$ ethanol in PB for $1 \mathrm{hr}$ and then $0.3 \%$ Triton X-100 in PB for $1 \mathrm{hr}$ before exposure to $\mathrm{ABC}$ solution (1:150; Vector Laboratories, Burlingame, $\mathrm{CA}$ ) in $\mathrm{PB}$ for $2-4 \mathrm{hr}$ at room temperature. After thorough washing in $\mathrm{PB}$ and Tris buffer (TB), $\mathrm{pH} 7.6$, sections were exposed to $0.04 \%$ diaminobenzidine and $0.3 \% \mathrm{NiCl}$ for $3 \mathrm{~min}$. Hydrogen peroxide was added to result in a $0.0025 \%$ solution, and sections were reacted for up to $1 \mathrm{hr}$. The reaction was stopped in washes of $\mathrm{TB}$, and the sections were cleared and coverslipped.

\section{Field potential and EEG recording during seizures}

As a positive control for disinhibition, perforant path-evoked field potential responses of the dentate gyrus were recorded in the presence of focally applied bicuculline, a $\mathrm{GABA}_{\mathrm{A}}$ receptor antagonist. Seizure-sensitive gerbils $(n=5)$ were anesthetized with urethane and prepared for perforant path stimulation and field potential recording in the dentate gyrus, as described above. The recording electrode was a patch pipette with a tip diameter of $\sim 15 \mu \mathrm{m}$ and with tubing inserted within so that the internal pipette solution could be changed. The perforant path was stimulated at $0.2 \mathrm{~Hz}$ with pairs of $150 \mu \mathrm{sec}$ constant-current stimuli at a $15 \mathrm{msec}$ interstimulus interval. Baseline responses were obtained for $10 \mathrm{~min}$ with $0.9 \% \mathrm{NaCl}$ in the pipette. Then the pipette solution was changed to $10 \mathrm{~mm}$ bicuculline in $0.9 \% \mathrm{NaCl}$. Similar methods have been used previously to produce focal blockade of $\mathrm{GABA}_{\mathrm{A}}$ receptor-mediated inhibition in the dentate gyrus (Sloviter and Brisman, 1995; Buckmaster and Dudek, 1997).

EEG recordings were obtained during "spontaneous" seizures triggered by novel environment exposure in 12 seizure-sensitive gerbils of both sexes. To implant electrodes, we anesthetized (pentobarbital, $60 \mathrm{mg} / \mathrm{kg}$, i.p.) gerbils, placed them in a stereotaxic frame, and maintained them on a heating pad with feedback control, as described above. By the use of aseptic surgical technique and the coordinates described above, a bipolar stimulating electrode (SNEX-200; Rhodes Medical Instruments) was directed toward the angular bundle, and a $25-\mu \mathrm{m}$-diameter insulated stainless steel recording electrode (California Fine Wire) was directed toward the border of the hilus and the granule cell layer in the dorsal hippocampus. Electrode depths were determined by optimizing field potential responses to stimulation. For recording neocortical EEG activity, a jeweler's screw was positioned $\sim 2 \mathrm{~mm}$ rostral and $\sim 2 \mathrm{~mm}$ lateral to the hole for the depth-recording electrode. Jeweler's screws for ground and reference leads were placed in the posterior cranium over the cerebellum. All leads were connected to a plug (Microtech, Boothwyn, PA), which was attached to the skull with cranioplastic cement (Plastics One, Roanoke, VA). Gerbils recovered at least $7 \mathrm{~d}$ before recordings began. EEG signals were filtered $(0.1-4000 \mathrm{~Hz})$ and amplified (AI 402 ultralow noise differential amplifiers and CyberAmp 380; Axon Instruments), observed on-line, and stored on computer (Clampex; Axon Instruments) and on videotape (Neuro-corder Neuro Data Instruments) for off-line analysis. EEG recordings began while the gerbil remained in its home cage and continued as the animal was exposed to the novel environment, as described above, that triggered a seizure. In five seizure-sensitive gerbils, at least one set of dentate gyrus responses to paired-pulse stimulation of the perforant path was obtained while the animal experienced a seizure. The perforant path was stimulated at $0.2 \mathrm{~Hz}$ with pairs of $150 \mu \mathrm{sec}$ constant-current stimuli at a $15 \mathrm{msec}$ interstimulus interval. Stimulus intensity was set just high enough (60-300 $\mu \mathrm{A}$ ) so that the first response of the pair consistently evoked a population spike during the baseline period before novel environment exposure. Pilot studies showed that these stimulation parameters did not trigger seizures and provided frequent responses for assessing the level of inhibition in the dentate gyrus. Population spike amplitude was measured from the peak negativity to an average of the peak positivities immediately before and after the spike. The amplitude ratio, defined as the amplitude of the second spike divided by the first of a pair, was used as a measure of paired-pulse inhibition. A reduction in paired-pulse inhibition is reflected, therefore, as an increase in the amplitude ratio.

\section{RESULTS}

\section{GABAergic neuron numbers}

In the dentate gyrus GABA-immunoreactive somata are found in all strata (hilus, granule cell layer, and molecular layer), but they are most abundant in the hilus, especially near the border of the hilus and the granule cell layer (Fig. $1 A$ ), as reported previously for GAD-immunoreactive neurons in gerbils (Peterson et al., 1985; Peterson and Ribak, 1987). GABA-immunoreactive somata at the surface of the section were labeled more intensely than were those in the middle of the section, and we could not exclude the possibility that some of the deep cells failed to reach the threshold for detection. Therefore, the optical fractionator method could not be used to estimate GABA-immunoreactive neuron numbers. Instead, the areal density of GABA-immunoreactive soma profiles was
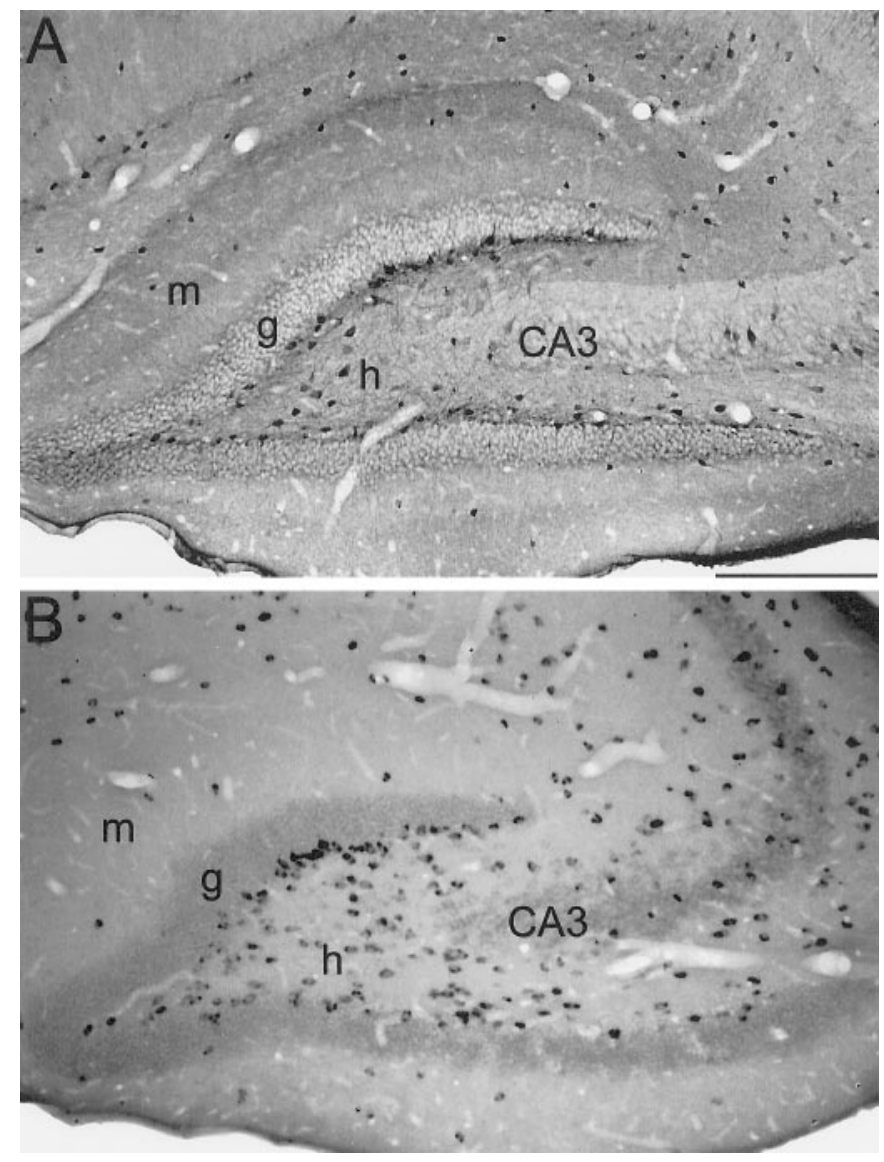

Figure 1. Sections from the septal half of the hippocampus in seizuresensitive gerbils showing GABA immunoreactivity $(A)$ and in situ hybridization of GAD67 mRNA $(B)$. GABAergic somata are most abundant in the hilus $(h)$, especially at the border of the hilus and the granule cell layer (g). $C A 3$, Proximal CA3 pyramidal cell layer; $m$, molecular layer. Scale bar, $250 \mu \mathrm{m}$.

calculated. Seizure-resistant and seizure-sensitive gerbils display similar densities of GABA-positive neurons in the dentate gyrus (Table 1).

The distribution of cells labeled by in situ hybridization of GAD67 mRNA (Fig. $1 B$ ) is similar to that of GABA-immunoreactive neurons. GAD67 mRNA-positive cells were labeled darkly throughout the thickness of the section, and the optical fractionator method was used to estimate the total number of GAD67 mRNA-positive neurons per dentate gyrus. Seizure-sensitive and seizure-resistant gerbils have similar numbers of GAD67 mRNA-positive neurons per dentate gyrus (Table 1).

Previous studies have reported that in the dorsal hippocampus of seizure-sensitive gerbils there are excess GABAergic interneurons concentrated in and around the superior blade of the granule cell layer (Peterson et al., 1985; Peterson and Ribak, 1987). Therefore, the density of GABA-immunoreactive soma profiles was measured, and the number of GAD67 mRNA-positive neurons was estimated for the subregion of the dentate gyrus including the superior granule cell layer and that portion of the molecular layer and hilus within $10 \mu \mathrm{m}$ of the cell layer. This analysis reveals no significant differences between seizure-resistant and seizure-sensitive gerbils (Table 1). Furthermore, the septotemporal distribution of GABAimmunoreactive soma density in the entire dentate gyrus (Fig. $2 A$ ) and in the superior granule cell layer (Fig. $2 B$ ) reveals no significant differences, except at the septotemporal level $45 \%$ of the way toward the temporal pole, where seizure-resistant gerbils have a significantly higher density of GABA-immunoreactive soma profiles than do seizure-sensitive gerbils ( $p<0.01, t$ test). The septotemporal distribution of GAD67 mRNA-positive neurons per section in the entire dentate gyrus (Fig. 2C) and in the superior 
Table 1. Interneuron densities and numbers in the dentate gyrus of seizure-resistant and seizure-sensitive gerbils

\begin{tabular}{lccc} 
& & $\begin{array}{c}\text { Seizure- } \\
\text { resistant }\end{array}$ & $\begin{array}{r}\text { Seizure- } \\
\text { sensitive }\end{array}$ \\
\hline GABA-immunoreactive neuron density (profiles $/ \mathrm{mm}^{2}$ ) & \\
Dentate gyrus & Mean & 175 & 170 \\
& SEM & 9 & 9 \\
Superior granule cell layer & Mean & 572 & 569 \\
& SEM & 27 & 34 \\
GAD67 mRNA-positive neurons & (number/dentate gyrus) & \\
Dentate gyrus & Mean & 18,788 & 18,124 \\
& SEM & 1,176 & 1,278 \\
& CE & 0.07 & 0.09 \\
\multicolumn{5}{c}{ Superior granule cell layer } & CV & 0.15 & 0.16 \\
& Mean & 4,329 & 4,585 \\
& SEM & 554 & 512 \\
\hline
\end{tabular}

There are no significant differences $(t$ test).

${ }^{\mathrm{a} C}$ Coefficient of error.

${ }^{\mathrm{b}}$ Coefficient of variation.

granule cell layer (Fig. 2D) reveals no significant difference between seizure-sensitive and seizure-resistant gerbils. The shape of the plots of GABA-immunoreactive neuron profile density differ from those of the number of GAD67 mRNA neurons per section, because the area of the dentate gyrus and the density of GABAergic interneurons vary along the septotemporal axis. Near the septal pole, for example, there are few GABAergic interneurons per section, but the area of the dentate gyrus is small, and the density of GABAergic interneurons is high.

\section{Granule cell IPSPs}

All of the cells from which intracellular recordings were obtained displayed morphological characteristics of granule cells (data not shown), including a soma within the granule cell layer, dendrites extending exclusively into the molecular layer, and an axon, with large mossy fiber boutons, projecting into the hilus of the dentate gyrus and stratum lucidum of CA3. The basic intrinsic electrophysiological features of granule cells are similar in seizure-sensitive and seizure-resistant gerbils (Table 2; Fig. $3 A$ ) and to those reported previously for rats from experiments using similar recording techniques (Buckmaster and Schwartzkroin, 1995; Buckmaster and Dudek, 1999). Input resistance is lower in seizure-sensitive gerbils, but the difference is not significant ( $t$ test). The action potential firing properties of granule cells appeared to be qualitatively similar between the groups and to those reported previously for rats, but they were not examined in detail.

The disinhibition hypothesis contends that in epileptic animals, granule cells are inadequately inhibited because the GABAergic interneurons that inhibit granule cells are excessively inhibited by other GABAergic interneurons (Peterson and Ribak, 1989). To test this prediction, IPSPs were evoked in granule cells by stimulating the perforant path in vivo. All of the granule cells responded to perforant path stimulation $(1.5 \times \mathrm{T})$ with a single action potential followed by a fast and slow IPSP (Fig. $3 B$ ). The IPSP conductances and reversal potentials (Fig. $3 C$ ), measured 20 and $150 \mathrm{msec}$ after the stimulus artifact, were similar in seizure-resistant and seizuresensitive gerbils and similar to those reported previously for rats in vivo (Buckmaster and Schwartzkroin, 1995; Buckmaster and Dudek, 1999).

\section{Dentate inhibition at seizure onset}

The disinhibition hypothesis contends that granule cells in the dorsal hippocampus are disinhibited at the onset of a seizure. What would disinhibition look like, using techniques currently available for recording from awake and unrestrained animals as they experience a seizure? To address this question, field potential recordings were obtained from the dentate gyrus in the dorsal hippocam-
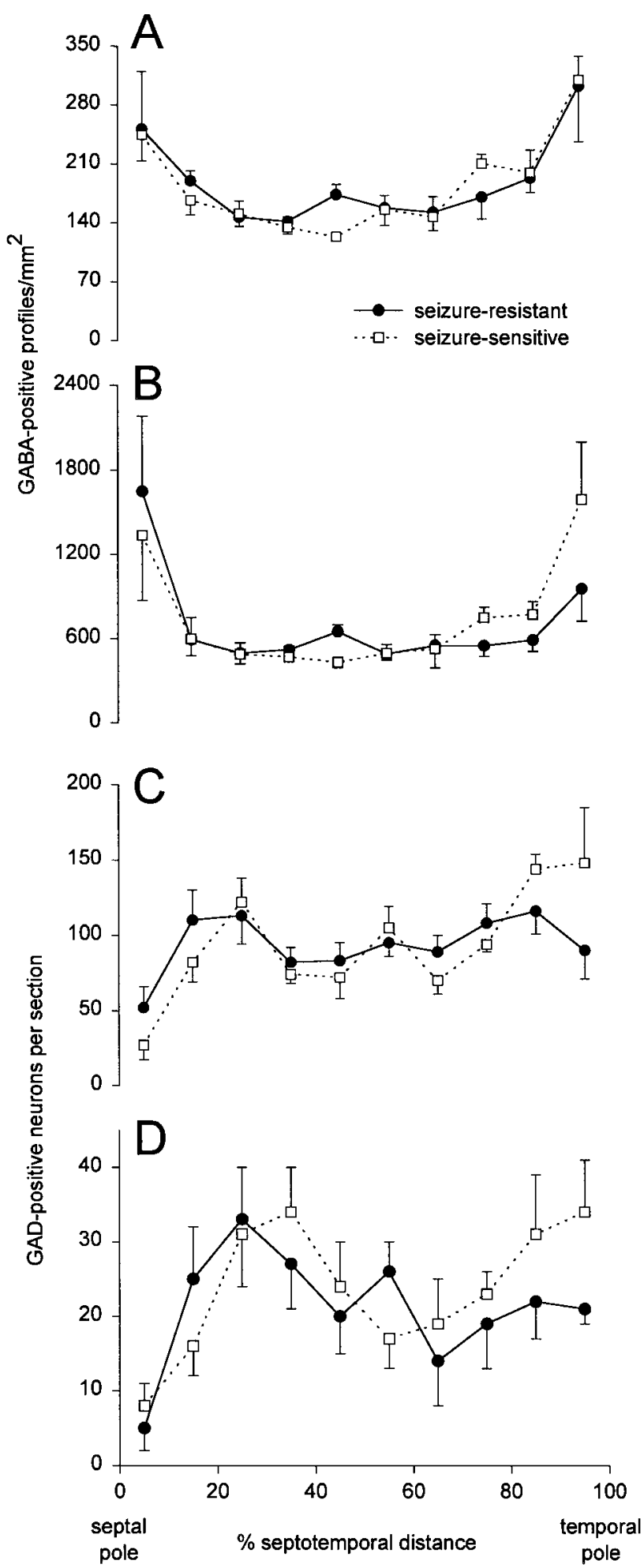

Figure 2. Density of GABA-immunoreactive somata $(A, B)$ and number of GAD67 mRNA neurons per section $(C, D)$ in the entire dentate gyrus $(A, C)$ and in and within $10 \mu \mathrm{m}$ of the superior granule cell layer $(B, D)$ in seizure-resistant (solid lines with filled circles) and seizure-sensitive (dashed lines with open squares) gerbils, plotted with respect to position along the septotemporal axis of the hippocampus. There were no significant differences except the GABA-immunoreactive soma profile density at $45 \%$ toward the temporal pole $(p<0.01, t$ test $)$. Error bars indicate SEM.

pus while the $\mathrm{GABA}_{\mathrm{A}}$ receptor antagonist bicuculline was focally applied in urethane-anesthetized seizure-sensitive gerbils $(n=5)$. Baseline responses to paired-pulse perforant path stimulation $(0.2$ $\mathrm{Hz} ; 150 \mu \mathrm{sec}$ duration; $15 \mathrm{msec}$ interstimulus interval; $0.25-1.50$ 
Table 2. Intrinsic electrophysiology and inhibitory postsynaptic potentials of granule cells in seizure-resistant and seizure-sensitive gerbils

\begin{tabular}{lcc} 
& $\begin{array}{c}\text { Seizure- } \\
\text { resistant }\end{array}$ & $\begin{array}{c}\text { Seizure- } \\
\text { sensitive }\end{array}$ \\
\hline$n$ (gerbils) & 12 & 11 \\
Intrinsic electrophysiology & & $-76 \pm 2$ \\
$\quad$ Resting membrane potential (mV) & $-77 \pm 2$ & $72 \pm 12$ \\
$\quad$ Input resistance $(\mathrm{M} \Omega)$ & $84 \pm 8$ & $75 \pm 3$ \\
$\quad$ Action potential amplitude (mV) & $73 \pm 2$ & \\
Inhibitory postsynaptic potentials & & \\
$\quad$ Fast (20 msec latency) & $21 \pm 5$ & $-69 \pm 1$ \\
$\quad$ Conductance (nS) & $-67 \pm 2$ & $6 \pm 1$ \\
$\quad$ Reversal potential (mV) & & $-85 \pm 4$ \\
$\quad$ Slow (150 msec latency) & $5 \pm 1$ & \\
$\quad$ Conductance (nS) & $-83 \pm 3$ & \\
$\quad$ Reversal potential (mV) & &
\end{tabular}

Values represent mean \pm SEM. There are no significant differences $(t$ test).

$\mathrm{mA}$ ) were obtained with $0.9 \% \mathrm{NaCl}$ in the recording pipette. During the baseline period, the response to the first pulse of the pair included a population spike that was $5-20 \mathrm{mV}$ in amplitude, and the response to the second pulse of the pair consisted of a field EPSP but no population spike (Fig. 4). After $10 \mathrm{~min}$ of baseline recording, the pipette solution was changed to $10 \mathrm{~mm}$ bicuculline in $0.9 \% \mathrm{NaCl}$. As bicuculline diffused from the electrode tip into the surrounding tissue, the average amplitude of the first population spike increased (Fig. 4, trace 2). Then paired-pulse inhibition began to decrease (i.e., the amplitude ratio increased) (Fig. 4, trace 3). Finally multiple population spikes appeared (Fig. 4, traces 4, 5). These findings suggest that if interneurons in the dentate gyrus were inactivated, as the hypothesis predicts, disinhibition of granule cells could be detected with the field potential recording techniques used in this experiment. Disinhibition could be recognized as an increase in population spike amplitude, a decrease in pairedpulse inhibition, and the appearance of multiple population spikes.

From EEG recordings in awake and unrestrained gerbils, seizure onset was identified by the appearance of repetitive electrographic spikes (Fig. 5). Seizures began seconds to minutes after placement in a novel environment $[197 \pm 61 \mathrm{sec}($ mean \pm SEM); range, 8-667 sec]. EEG recordings were obtained simultaneously from the dentate gyrus and ipsilateral neocortex during 7 seizures in seven gerbils without perforant path stimulation and in 12 seizures in five additional gerbils during perforant path stimulation. In all cases electrographic spikes appeared simultaneously or nearly simultaneously in the neocortex and dentate gyrus. As a seizure began, a gerbil would stop exploring the environment and remain motionless for a brief period, and then clonic movements of the ears and head would quickly generalize into motor convulsions involving the entire body. Electrographic spikes preceded the onset of the clonic movements by $2-11$ sec $[5 \pm 1 \mathrm{sec}($ mean \pm SEM) $]$.

During the preseizure baseline period, perforant path stimulation $(0.2 \mathrm{~Hz} ; 150 \mu \mathrm{sec}$ duration; $15 \mathrm{msec}$ interstimulus interval) evokes a first population spike with an average amplitude of 5.8 $\mathrm{mV}$. The average amplitude ratio is 0.16 , indicating strong pairedpulse inhibition (Figs. 6, trace 1, 7B). Responses immediately before and after seizure onset are similar to baseline values (Figs. 6, trace 2, 7), indicating that granule cell disinhibition does not occur before seizure onset. However, as the seizure continues, evidence of reduced inhibition appears. First, the amplitude of the first population spike increases (Fig. 6, top, trace 3). This is more apparent in plots of individual responses (Fig. 6, top) than in the plot of averaged responses (Fig. $7 A$ ), because variation in the timing of the peak in the population spike amplitude and the subsequent small-amplitude responses reduce the average. The peak amplitude of the first population spike is $2.0 \pm 0.2$ times the baseline value (mean $\pm \mathrm{SEM}$ ), and it occurs $10 \pm 2 \mathrm{sec}$ after seizure onset. Next,
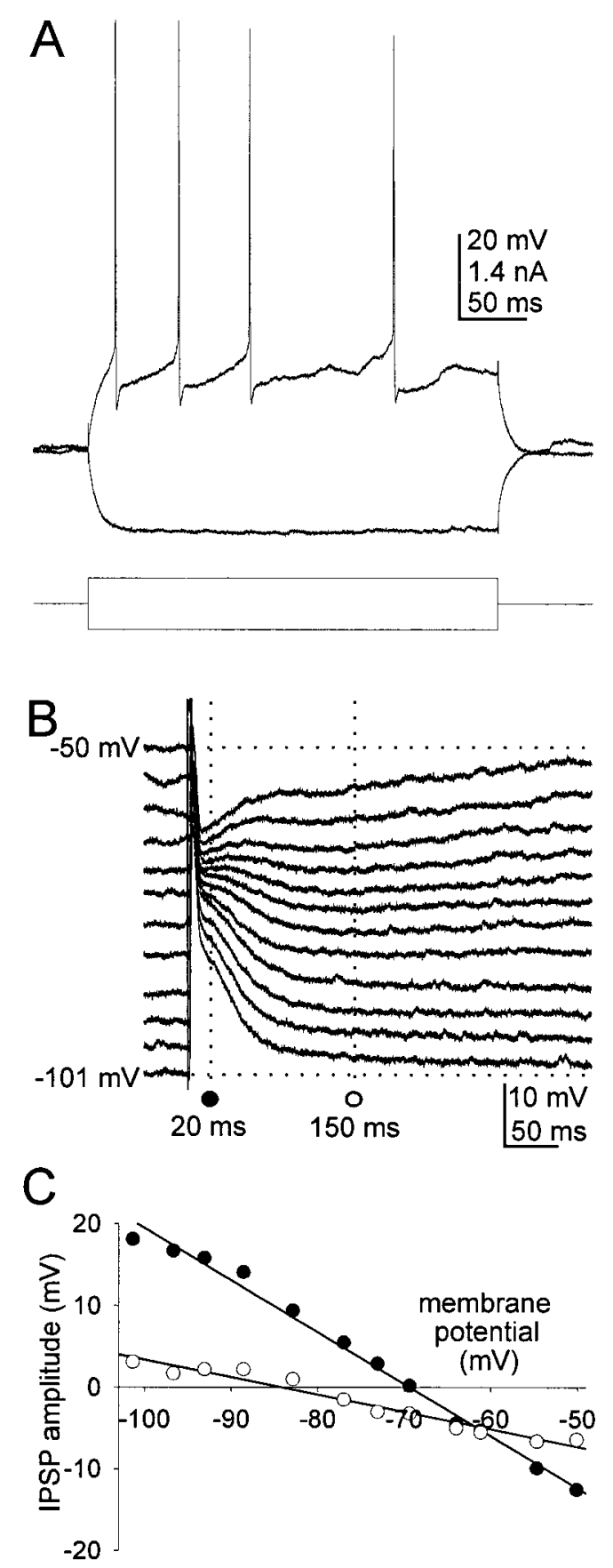

Figure 3. In vivo intracellular recordings from a granule cell in the dorsal hippocampus of a seizure-sensitive gerbil. $A$, Responses to intracellular current injection reveal typical granule cell intrinsic physiological characteristics that are similar in seizure-sensitive and seizure-resistant gerbils. Top traces are membrane potential; bottom traces are current. B, Perforant path stimulation at $1.5 \times$ T evoked an action potential followed by a fast and slow IPSP. DC current was used to alter the membrane potential. The cell's resting membrane potential was $-77 \mathrm{mV}$. IPSP conductances were calculated from responses like these. $C$, IPSP amplitude, measured at $20 \mathrm{msec}$ ( filled circles) or $150 \mathrm{msec}$ (open circles) after the stimulus artifact, plotted against membrane potential reveals IPSP reversal potentials of $-70 \mathrm{mV}$ for the fast IPSP and $-84 \mathrm{mV}$ for the slow IPSP.

the amplitude ratio increases (i.e., paired-pulse inhibition decreases) (Figs. 6, middle, traces 3, 4, 6, 7B). Then multiple population spikes appear. The maximum number of population spikes evoked by a single stimulus is $3.6 \pm 0.4$, and the latency from seizure onset to the first response with multiple population spikes is $18 \pm 2 \mathrm{sec}$. Multiple population spikes were never observed during baseline recording. After the appearance of multiple population spikes, the amplitude of the responses decreases until stimulation evokes no change in the 

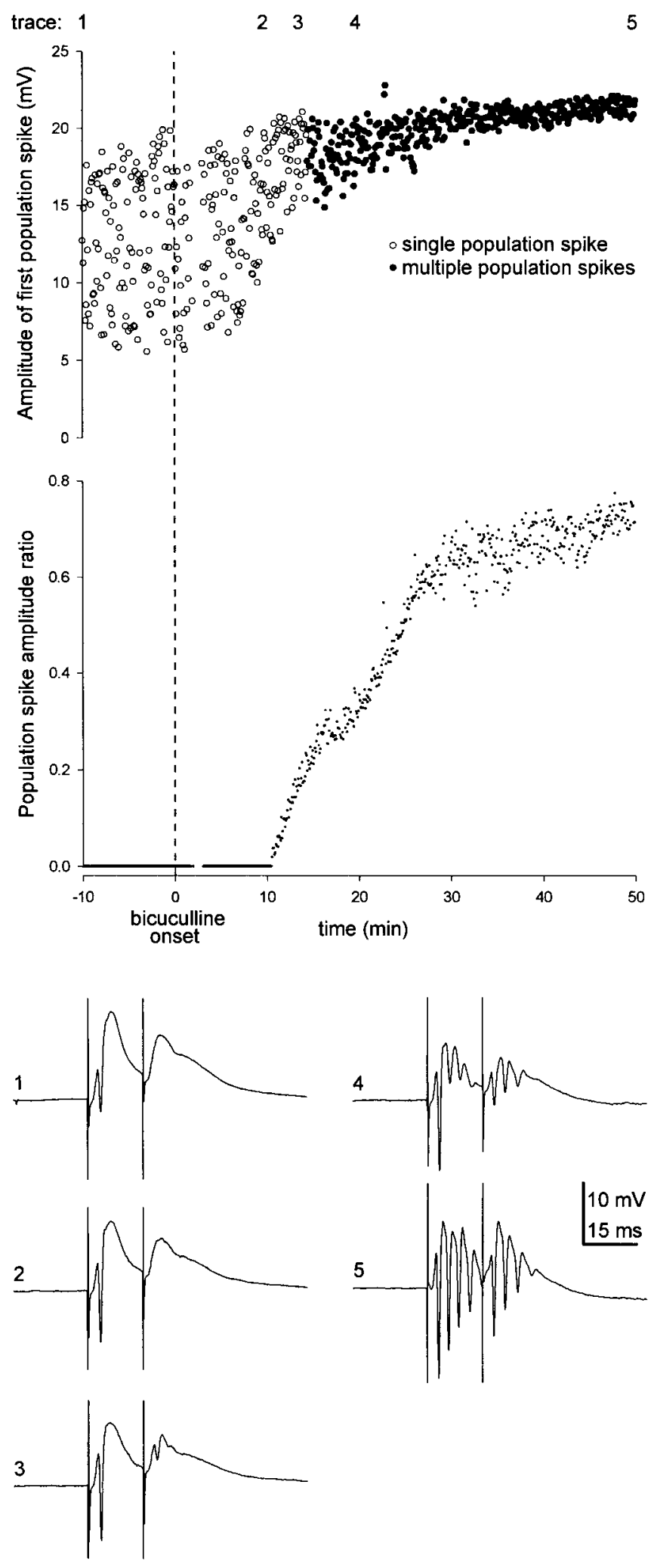

Figure 4. A positive control for disinhibition in the dentate gyrus. Dentate gyrus field potential responses to perforant path stimulation were obtained from the dorsal hippocampus of a urethane-anesthetized seizure-sensitive gerbil. After $10 \mathrm{~min}$ of baseline recording (trace 1), the recording pipette solution was changed to $10 \mathrm{~mm}$ bicuculline to block $\mathrm{GABA}_{\mathrm{A}}$ receptormediated inhibition focally. As bicuculline diff uses into the tissue, the field potential responses display evidence of progressive loss of granule cell inhibition. The average amplitude of the population spike of the first response increases (trace 2). Paired-pulse inhibition decreases (traces 3-5), reflected by an increase in the population spike amplitude ratio, and multiple population spikes appear (traces 4,5$)$.

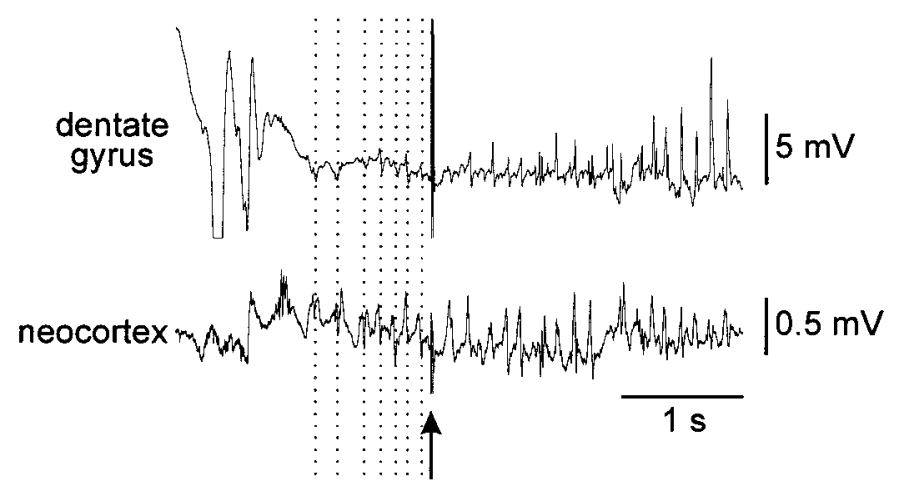

Figure 5. Seizure onset identified by electrographic spiking in the dentate gyrus of the dorsal hippocampus (top) and in the neocortex (bottom). This EEG was obtained during perforant path stimulation (arrow). The first seven electrographic spikes of the seizure are indicated by dashed lines, and they occur simultaneously in the dentate gyrus and neocortex. As the seizure continues, the spikes in the dentate gyrus become large-amplitude positive deflections.

field potential (Fig. 6, trace 5). The latency from seizure onset of this nonresponsive period is $30 \pm 4 \mathrm{sec}$, and the duration is $45 \pm 9 \mathrm{sec}$. After this period, dentate gyrus field potential responses gradually return, although amplitude ratios are high and in some cases multiple population spikes are evoked (Fig. 6, middle, trace 6), indicating reduced inhibition. Responses recovered to a normal waveform, similar to that obtained during the baseline period, by $130 \pm 8 \mathrm{sec}$ after seizure onset.

\section{DISCUSSION}

The principal findings of this study are as follows: (1) Seizureresistant and seizure-sensitive gerbils have similar densities of GABA-immunoreactive somata and similar numbers of GAD67 mRNA-positive neurons in the dentate gyrus. (2) Granule cells in the dorsal hippocampus of seizure-resistant and seizure-sensitive gerbils have similar IPSP conductances and reversal potentials. (3) Seizure-sensitive gerbils do not display evidence of disinhibition in the dentate gyrus of the dorsal hippocampus at the onset of a spontaneous seizure. These findings argue against the disinhibition hypothesis as proposed for gerbils with inherited epilepsy (Peterson and Ribak, 1989).

\section{The disinhibition hypothesis}

Excitability of cortical circuits varies with respect to an animal's behavioral state (Castro-Alamancos and Connors, 1996), and as a rodent explores a novel environment, the level of excitability of dentate granule cells is dynamically controlled by inhibitory mechanisms (Moser, 1996). How is inhibitory control modulated in the dentate gyrus? One possibility is disinhibition mediated by GABAergic interneurons. GABAergic interneurons in the dentate gyrus have dense and far-reaching axon arbors (Struble et al., 1978; Han et al., 1993; Buckmaster and Schwartzkroin, 1995; Sik et al., 1997), and individual hippocampal interneurons affect the activity of many principal cells (Cobb et al., 1995). Therefore the inhibition of GABAergic interneurons (i.e., disinhibition) could be an effective mechanism for adjusting inhibitory control of dentate granule cells. In fact, vasoactive intestinal polypeptide-immunoreactive interneurons, a class of GABAergic interneurons in the dentate gyrus, form inhibitory contacts specifically with other GABAergic interneurons (Hajos et al., 1996).

In the dentate gyrus of patients and models of temporal lobe epilepsy, inhibitory interneurons are preferentially spared from injuries that kill many glutamatergic neurons, and the axons of surviving GABAergic neurons appear to sprout and form new synaptic contacts (Babb et al., 1989; Davenport et al., 1990; Mathern et al., 1995). These findings suggest that disinhibitory circuits may be abnormally exaggerated after epileptogenic brain injuries. In the present study we tested the disinhibition hypothesis in the 

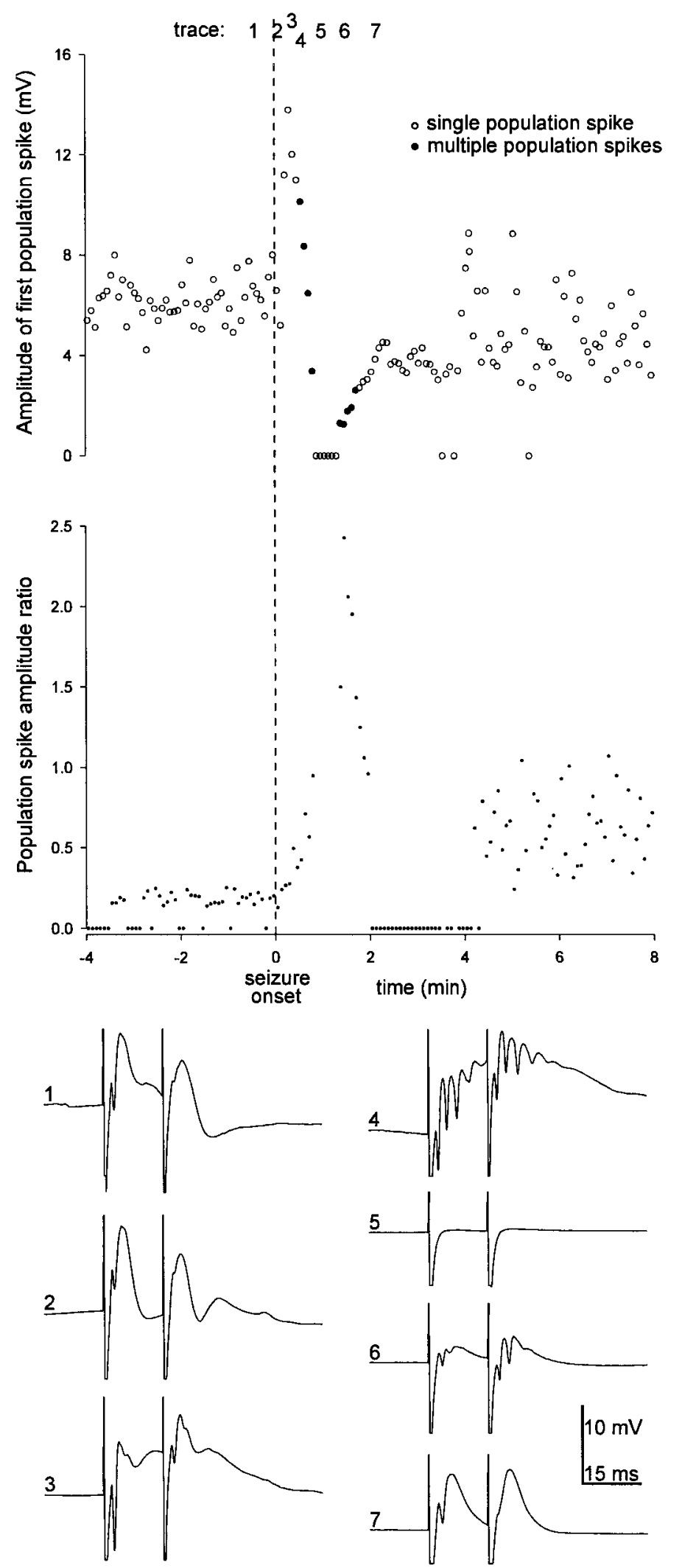

A
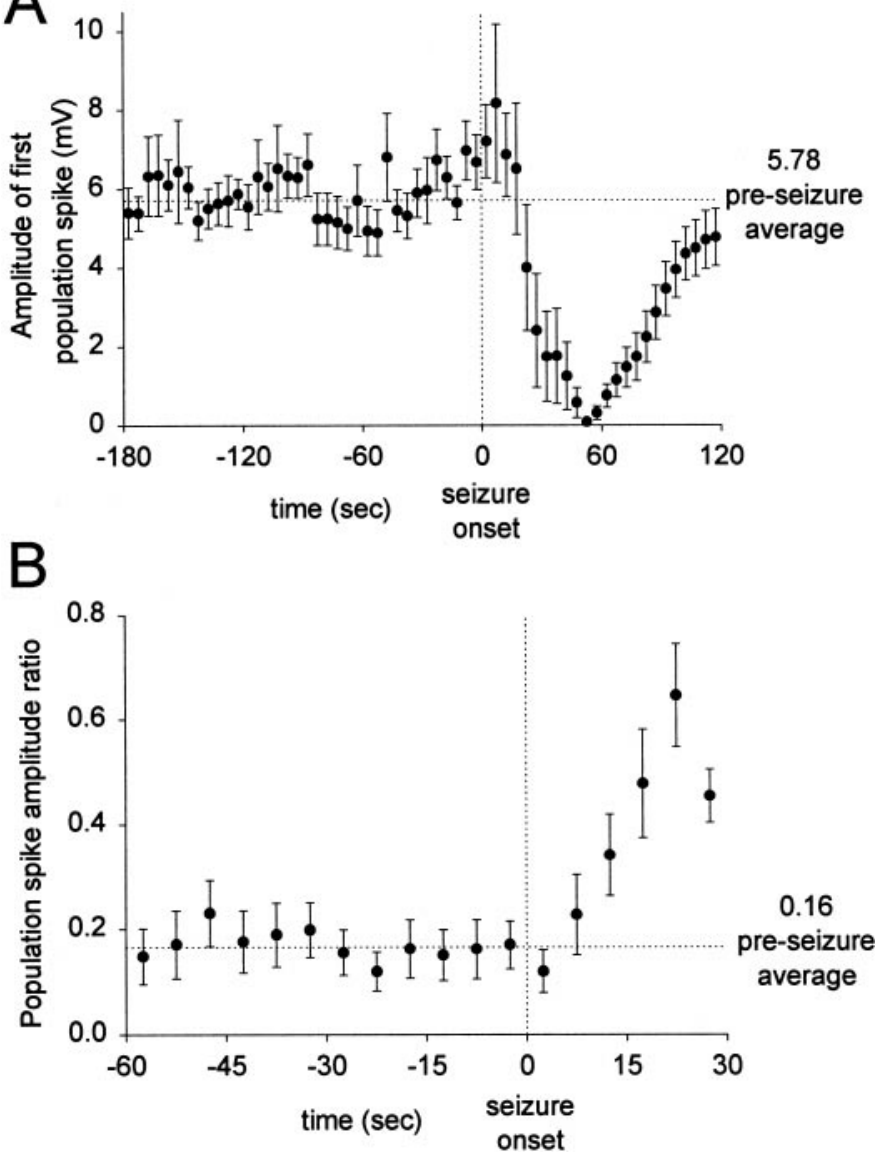

Figure 7. Average responses of the dentate gyrus to paired-pulse stimulation during 12 spontaneous seizures in five epileptic gerbils. The amplitude of the first population spike $(A)$ and the population spike amplitude ratio $(B)$ remain near their average preseizure baseline values until after seizure onset. As the seizure continues, the population spike amplitude ratio increases, and the amplitude of the first population spike peaks and then goes to zero before gradually returning to preseizure values as the animal recovers from the seizure.

experimental model of inherited epilepsy that inspired it. Evidence from anatomical, in vivo intracellular, and EEG experiments does not support the disinhibition hypothesis of epileptogenesis.

\section{Anatomy}

Contrary to previous reports (Peterson et al., 1985; Peterson and Ribak, 1987), we did not find excess GABAergic interneurons in the dentate gyrus of the dorsal hippocampus in epileptic gerbils. Similarly, we previously found no differences between seizure-resistant and seizure-sensitive gerbils in the numbers of somatostatin- and parvalbumin-immunoreactive interneurons, which are major classes of GABAergic interneurons in the dentate gyrus (Buckmaster et al., 1996). Our results might differ from other studies because newer staining techniques that use more recently developed antibodies for GABA and in situ hybridization of GAD67 mRNA are more sensitive for detecting GABAergic interneurons than are previous GADimmunocytochemical methods (Szabat et al., 1992; Obenaus et al., 1993; Houser and Esclapez, 1994; Esclapez and Houser, 1995). In previous GAD-immunocytochemical studies, epileptic gerbils might have appeared to have more GAD-immunoreactive neurons because

Figure 6. Dentate gyrus responses to paired-pulse stimulation $(0.2$ before, during, and after the onset of a spontaneous seizure in an epileptic gerbil. The first two pairs of responses after seizure onset (trace 2) are similar to those obtained during the preseizure period (trace 1). As the seizure continues, evidence of progressive failure of granule cell inhibition appears. The amplitude of the first population spike increases (trace 3). Paired-pulse inhibition decreases (traces 3,4), indicated by an increase in the population spike amplitude ratio, and multiple population spikes are evoked (trace 4 ). Then, electrographic spiking stops, and perforant path stimulation evokes no change in the field potential (trace 5). After the $\leftarrow$ (trace 6), before returning to waveforms similar to those obtained during the preseizure period (trace 7). Error bars indicate SEM. nonresponsive period, evoked responses gradually return. Initially they display multiple population spikes and reduced paired-pulse inhibition 
seizure activity increases the expression of GAD (Feldblum et al., 1990; Schwarzer and Sperk, 1995; Esclapez and Houser, 1999), possibly bringing borderline cells beyond the threshold for detection in epileptic but not control gerbils.

Despite normal GABAergic interneuron numbers, epileptic gerbils might have an abnormally exaggerated disinhibitory circuit, and our anatomical results do not exclude this possibility. In fact, GABAergic interneurons in the dentate gyrus of epileptic gerbils are reported to receive more inhibitory synaptic contacts than are those in control animals (Peterson et al., 1985; Peterson and Ribak, 1989; Farias et al., 1992). The experiments of the present study did not directly measure the degree of inhibitory input to GABAergic interneurons. However, if seizure-sensitive gerbils had an exaggerated disinhibitory circuit, one would expect to find evidence of reduced inhibition of granule cells. To test this possibility, granule cell IPSPs were evaluated.

\section{IPSPs in granule cells}

We examined IPSPs in granule cells of urethane-anesthetized gerbils, and recordings were obtained in vivo to avoid disrupting disinhibitory circuits. We found no differences in the conductances and reversal potentials of IPSPs in granule cells of seizure-sensitive and seizure-resistant gerbils. These findings show that IPSPs evoked during the interictal period are similar in epileptic and control gerbils. However, our evoked IPSP results do not exclude the possibility that other measures of inhibitory input to granule cells may detect differences between epileptic and control gerbils. Although the IPSP results show no evidence of disinhibition of granule cells in epileptic gerbils, the level of inhibitory control of the dentate gyrus is dynamically modulated (Moser, 1996). Therefore, it is possible that spontaneous seizures are triggered by brief but sufficiently severe episodes of disinhibition that are not evident during the interictal period. To test this possibility, we obtained field potential recordings from the dentate gyrus of the dorsal hippocampus as naturally epileptic gerbils experienced spontaneous seizures.

\section{EEGs during spontaneous seizures}

Previous studies of patients and models with epilepsy have recorded responses to paired-pulse stimulation to measure the level of inhibitory control in the dentate gyrus in vivo during the interictal period (Buckmaster et al., 1996; Wilson et al., 1998). Other studies have provided detailed analyses of EEG activity recorded with depth electrodes in the dentate gyrus at the onset of spontaneous seizures (Spencer et al., 1992; Bragin et al., 1999). To our knowledge, the present study is the first reported attempt to measure inhibition in the dentate gyrus during the onset of spontaneous seizures.

This novel approach raises technical questions. First, it might be thought that a $0.2 \mathrm{~Hz}$ sampling interval is too infrequent to detect a brief reduction in inhibition that could trigger a seizure. However, evoked responses immediately before and after the seizure onset were similar to those obtained during the preseizure baseline period, suggesting that the preseizure level of inhibition was maintained through seizure onset. Second, field potential recording is a limited technique for measuring granule cell inhibition, because synchronously stimulating many axons in the perforant path is not a physiologically normal mode of stimulation, and the underlying mechanisms that affect field potential responses cannot be discerned without using other recording techniques and in vitro preparations. Furthermore, population spike amplitude is proportional to the number of granule cells discharging an action potential (Andersen et al., 1971), and the probability that a granule cell will discharge an action potential depends on many factors in addition to the level of inhibitory control. Despite these limitations, field potential recordings offer the advantages that they reflect the activity of a population of neurons (seizures are a population phenomenon) and that they can be obtained from animals experiencing spontaneous seizures. We believe that the field potential-recording technique used in this study is sufficiently sensitive to detect reductions in granule cell inhibition that might trigger a seizure, because positive controls reveal dramatic changes in field potential responses when $\mathrm{GABA}_{\mathrm{A}}$ receptor-mediated inhibition was focally blocked with bicuculline at the recording site and because we found progressively diminishing inhibition of granule cells after the seizure had begun.

The disinhibition hypothesis contends that seizures begin when granule cells in the dentate gyrus of the dorsal hippocampus are disinhibited. On the contrary, our findings show that the inhibition of granule cells in this region, assessed with evoked field potentials, is maintained through the onset of spontaneous seizures. These results indicate that granule cell disinhibition in the dorsal hippocampus does not initiate seizures in this experimental model. However, after a seizure continues for $>5 \mathrm{sec}$, signs of reduced inhibition begin to appear. These findings are similar to a previous study in which seizures in the dentate gyrus were evoked in normal rats by tetanic stimulation (Emori et al., 1997). In that study like in ours, paired-pulse inhibition failed after, but not before, seizure onset. During tetanic stimulation the efficacy of GABA-mediated inhibition in the hippocampus decreases (for review, see Thompson, 1994). The mechanisms of activity-dependent depression of IPSPs include reduction of the driving force for chloride ions by accumulation of potassium ions extracellularly and chloride ions intracellularly and reduction of the IPSP conductance by presynaptic inhibition of GABA release. These same mechanisms may be activated by seizures, and seizure-induced reductions of granule cell inhibition could contribute to the amplification and spread of epileptic activity to other brain regions.

\section{What causes inherited epilepsy in gerbils?}

The results of this study indicate that seizure genesis in gerbils with inherited epilepsy does not involve an imbalance of GABAergic neuron numbers in the dentate gyrus or the loss of GABAergic inhibition of granule cells in the dorsal hippocampus. The underlying mechanisms of inherited epilepsy in Mongolian gerbils remain unclear. However, there is an alternative hypothesis for epileptogenesis in gerbils. Gerbils display features characteristic of generalized idiopathic epileptic syndromes (Blume and Wolf, 1997), and recently several such syndromes have been associated with mutations of ion channels (for review, see Bate and Gardiner, 1999). Olsen et al. (1985) reported that there are significantly fewer benzodiazepinebinding $\mathrm{GABA}_{\mathrm{A}}$ receptors in the midbrain (but no difference in the dentate gyrus) in adult seizure-sensitive gerbils and 30-d-old seizure-predisposed gerbils (before the onset of behaviorally detectable seizures) compared with seizure-resistant gerbils. Previously it has been shown that disruption of $\mathrm{GABA}_{\mathrm{A}}$ receptor subunits can cause epilepsy (DeLorey et al., 1998). These findings, therefore, make $\mathrm{GABA}_{\mathrm{A}}$ receptor subunits candidates for mutations that might impair inhibition in the midbrain and cause inherited epilepsy in gerbils and possibly in other species.

\section{REFERENCES}

Andersen P, Bliss TVP, Skrede KK (1971) Unit analysis of hippocampal population spikes. Exp Brain Res 13:208-221.

Babb TL, Pretorius JK, Kupfer WR, Crandall PH (1989) Glutamate decarboxylase-immunoreactive neurons are preserved in human epileptic hippocampus. J Neurosci 9:2562-2574.

Bate L, Gardiner M (1999) Genetics of inherited epilepsies. Epileptic Disorders 1:7-19.

Bekenstein JW, Lothman EW (1993) Dormancy of inhibitory interneurons in a model of temporal lobe epilepsy. Science 259:97-100.

Blume WT, Wolf P (1997) Introduction to the epilepsies. In: Epilepsy: a comprehensive textbook (Engel Jr J, Pedley TA, eds), pp 765-772. Philadelphia: Lippincott-Raven.

Bragin A, Engel Jr J, Wilson CL, Vizentin E, Mathern GW (1999) Electrophysiologic analysis of a chronic seizure model after unilateral hippocampal KA injection. Epilepsia 40:1210-1221.

Brooks-Kayal AR, Shumate MD, Jin H, Rikhter TY, Coulter DA

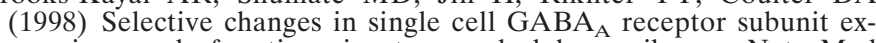
pression and function in temporal lobe epilepsy. Nat Med 4:1166-1172. 
Buckmaster PS, Dudek FE (1997) Network properties of the dentate gyrus in epileptic rats with hilar neuron loss and granule cell axon reorganization. J Neurophysiol 77:2685-2696.

Buckmaster PS, Dudek FE (1999) In vivo intracellular analysis of granule cell axon reorganization in epileptic rats. J Neurophysiol 81:712-721.

Buckmaster PS, Jongen-Rêlo AL (1999) Highly specific neuron loss preserves lateral inhibitory circuits in the dentate gyrus of kainateinduced epileptic rats. J Neurosci 19:9519-9529.

Buckmaster PS, Schwartzkroin PA (1995) Interneurons and inhibition in the dentate gyrus of the rat in vivo. J Neurosci 15:774-789.

Buckmaster PS, Tam E, Schwartzkroin PA (1996) Electrophysiological correlates of seizure sensitivity in the dentate gyrus of epileptic juvenile and adult gerbils. J Neurophysiol 76:2169-2180.

Buelke-Sam J, Holson JF, Bazare JJ, Young JF (1978) Comparative stability of physiological parameters during sustained anesthesia in rats. Lab Anim Sci 28:157-162.

Buhl EH, Otis TS, Mody I (1996) Zinc-induced collapse of augmented inhibition by GABA in a temporal lobe epilepsy model. Science $271: 369-373$

Castro-Alamancos MA, Connors BW (1996) Short-term plasticity of a thalamocortical pathway dynamically modulated by behavioral state. Science 272:274-277.

Cobb SR, Buhl EH, Halasy K, Paulsen O, Somogyi P (1995) Synchronization of neuronal activity in hippocampus by individual GABAergic interneurons. Nature 378:75-78.

Davenport CJ, Brown WJ, Babb TL (1990) Sprouting of GABAergic and mossy fiber axons in dentate gyrus following intrahippocampal kainate in the rat. Exp Neurol 109:180-190.

de Lanerolle NC, Kim JH, Robbins RJ, Spencer DD (1989) Hippocampal interneuron loss and plasticity in human temporal lobe epilepsy. Brain Res 495:387-395.

DeLorey TM, Handforth A, Anagnostaras SG, Homanics GE, Minassian BA, Asatourian A, Fanselow MS, Delgado-Escueta A, Ellison GD, Olsen RW (1998) Mice lacking the $\beta 3$ subunit of the GABA receptor have the epilepsy phenotype and many of the behavioral characteristics of Angelman syndrome. J Neurosci 18:8505-8514.

During MJ, Ryder KM, Spencer DD (1995) Hippocampal GABA transporter function in temporal-lobe epilepsy. Nature 376:174-177.

Emori K, Katsumori H, Minabe Y (1997) Changes in paired-pulse depression during the triggering of seizures by $2 \mathrm{~Hz}$ dentate gyrus stimulation: effect of the kindling. Brain Res 776:250-254.

Engel Jr J, Williamson PD, Wieser H-G (1997) Mesial temporal lobe epilepsy. In: Epilepsy: a comprehensive textbook (Engel Jr J, Pedley TA, eds), pp 2417-2426. Philadelphia: Lippincott-Raven.

Esclapez M, Houser CR (1995) Somatostatin neurons are a subpopulation of GABA neurons in the rat dentate gyrus: evidence from colocalization of pre-prosomatostatin and glutamate decarboxylase messenger RNAs. Neuroscience 64:339-355.

Esclapez M, Houser CR (1999) Up-regulation of GAD65 and GAD67 in remaining hippocampal GABA neurons in a model of temporal lobe epilepsy. J Comp Neurol 412:488-505.

Farias PA, Low SQ, Peterson GM, Ribak CE (1992) Morphological evidence for altered synaptic organization and structure in the hippocampal formation of seizure-sensitive gerbils. Hippocampus 2:229-246.

Feldblum S, Ackermann RF, Tobin AJ (1990) Long-term increase of glutamate decarboxylase mRNA in a rat model of temporal lobe epilepsy. Neuron 5:361-371.

Fukuda T, Heizmann CW, Kosaka T (1997) Quantitative analysis of GAD65 and GAD67 immunoreactivities in somata of GABAergic neurons in the mouse hippocampus proper (CA1 and CA3 regions), with special reference to parvalbumin-containing neurons. Brain Res 764:237-243.

Hajos N, Acsady L, Freund TF (1996) Target selectivity and neurochemical characteristics of VIP-immunoreactive interneurons in the rat dentate gyrus. Eur J Neurosci 8:1415-1431.

Han Z-S, Buhl EH, Lörinczi Z, Somogyi P (1993) A high degree of spatial selectivity in the axonal and dendritic domains of physiologically identified local-circuit neurons in the dentate gyrus of the rat hippocampus. Eur J Neurosci 5:395-410.

Houser CR, Esclapez M (1994) Localization of mRNAs encoding two forms of glutamic acid decarboxylase in the rat hippocampal formation. Hippocampus 4:530-545.

Jongen-Rêlo AL, Pitkänen A，Amaral DG (1999) Distribution of
GABAergic cells and fibers in the hippocampal formation of the macaque monkey: an immunohistochemistry and in situ hybridization study. J Comp Neurol 408:237-271.

Loskota WJ, Lomax P (1975) The Mongolian gerbil (Meriones unguiculatus) as a model for the study of the epilepsies: EEG records of seizures. Electroencephalogr Clin Neurophysiol 38:597-604.

Loskota WJ, Lomax P, Rich ST (1974) The gerbil as a model for the study of the epilepsies. Epilepsia 15:109-119.

Ludvig N, Farias PA, Ribak CE (1991) An analysis of various environmental and specific sensory stimuli on the seizure activity of the Mongolian gerbil. Epilepsy Res 8:30-35.

Majkowski J, Donadio M (1984) Electro-clinical studies of epileptic seizures in Mongolian gerbils. Electroencephalogr Clin Neurophysiol 57:369-377.

Mathern GW, Babb TL, Pretorius JK, Leite JP (1995) Reactive synaptogenesis and neuron densities for neuropeptide $\mathrm{Y}$, somatostatin, and glutamate decarboxylase immunoreactivity in the epileptic human fascia dentata. J Neurosci 15:3990-4004.

Moser EI (1996) Altered inhibition of dentate granule cells during spatial learning in an exploration task. J Neurosci 16:1247-1259.

Obenaus A, Esclapez M, Houser CR (1993) Loss of glutamate decarboxylase mRNA-containing neurons in the rat dentate gyrus following pilocarpine-induced seizures. J Neurosci 13:4470-4485.

Olsen RW, Wamsley JK, McCabe RT, Lee RJ, Lomax P (1985) Benzodiazepine/ $\gamma$-aminobutyric acid receptor deficit in the midbrain of the seizure-sensitive gerbil. Proc Natl Acad Sci USA 82:6701-6705.

Paul LA, Fried I, Watanabe K, Forsythe AB, Scheibel AB (1981) Structural correlates of seizure behavior in the Mongolian gerbil. Science 213:924-926.

Peterson GM, Ribak CE (1987) Hippocampus of the seizure-sensitive gerbil is a specific site for anatomical changes in the GABAergic system. J Comp Neurol 261:405-422.

Peterson GM, Ribak CE (1989) Relationship of the hippocampal GABAergic system and genetic epilepsy in the seizure-sensitive gerbil. In: The hippocampus-new vistas (Chan-Palay V, Köhler C, eds), pp 483-497. New York: Liss.

Peterson GM, Ribak CE, Oertel WH (1985) A regional increase in the number of hippocampal GABAergic neurons and terminals in the seizure-sensitive gerbil. Brain Res 340:384-389.

Ramón y Cajal S (1995) Histology of the nervous system, Vol II (Swanson N, Swanson LW, translators), pp 615-618. New York: Oxford.

Ribak CE, Khan SU (1987) The effects of knife cuts of hippocampal pathways on epileptic activity in the seizure-sensitive gerbil. Brain Res 418:146-151.

Schwarzer C, Sperk G (1995) Hippocampal granule cells express glutamic acid decarboxylase-67 after limbic seizures in the rat. Neuroscience 69:705-709.

Shirasaka Y, Wasterlain CG (1995) The effect of urethane anesthesia on evoked potentials in dentate gyrus. Eur J Pharmacol 282:11-17.

Sik A, Penttonen M, Buzsáki G (1997) Interneurons in the hippocampal dentate gyrus: an in vivo intracellular study. Eur J Neurosci 9:573-588.

Sloviter RS (1987) Decreased hippocampal inhibition and a selective loss of interneurons in experimental epilepsy. Science 235:73-76.

Sloviter RS, Brisman JL (1995) Lateral inhibition and granule cell synchrony in the rat hippocampal dentate gyrus. J Neurosci 15:811-820.

Spencer SS, Guimaraes P, Katz A, Kim J, Spencer D (1992) Morphological patterns of seizures recorded intracranially. Epilepsia 33:537-545.

Struble RG, Desmond NL, Levy WB (1978) Anatomical evidence for interlamellar inhibition in the fascia dentata. Brain Res 152:580-585.

Szabat E, Soinila S, Happola O, Linnala A, Virtänen I (1992) A new monoclonal antibody against the GABA-protein conjugate shows immunoreactivity in sensory neurons of the rat. Neuroscience 47:409-420.

Thompson SM (1994) Modulation of inhibitory synaptic transmission in the hippocampus. Prog Neurobiol 42:575-609.

West MJ, Slomianka L, Gundersen HJG (1991) Unbiased stereological estimation of the total number of neurons in the subdivisions of the rat hippocampus using the optical fractionator. Anat Rec 231:482-497.

Williamson A, Patrylo PR, Spencer DD (1999) Decrease in inhibition in dentate granule cells from patients with medial temporal lobe epilepsy. Ann Neurol 45:92-99.

Wilson CL, Khan SU, Engel Jr J, Isokawa M, Babb TL, Behnke EJ (1998) Paired pulse suppression and facilitation in human epileptogenic hippocampal formation. Epilepsy Res 31:211-230. 